\title{
Randomised controlled trial of budesonide for the prevention of post-bronchiolitis wheezing
}

\author{
Grenville F Fox, Mark L Everard, Michael J Marsh, Anthony D Milner
}

\begin{abstract}
Background-Previous studies suggest that recurrent episodes of coughing and wheezing occur in up to $75 \%$ of infants after acute viral bronchiolitis.

Aim-To assess the efficacy of budesonide given by means of a metered dose inhaler, spacer, and face mask in reducing the incidence of coughing and wheezing episodes up to 12 months after acute viral bronchiolitis.

Methods-Children under the age of 12 months admitted to hospital with acute viral bronchiolitis were randomised to receive either budesonide or placebo $(200 \mu \mathrm{g}$ or one puff twice daily) for the next eight weeks. Parents kept a diary card record of all episodes of coughing and wheezing over the next 12 months.

Results-Full follow up data were collected for 49 infants. There were no significant differences between the two study groups for the number of infants with symptom episodes up to six months after hospital discharge. At 12 months, 21 infants in the budesonide group had symptom episodes compared with 12 of 24 in the placebo group. The median number of symptom episodes was 2 (range, 0-13) in those who received budesonide and 1 (range, 0-11) in those who received placebo. Because there is no pharmacological explanation for these results, they are likely to be caused by a type 1 error, possibly exacerbated by there being more boys in the treatment group.

Conclusion-Routine administration of budesonide by means of a metered dose inhaler, spacer, and face mask system immediately after acute viral bronchiolitis cannot be recommended.

(Arch Dis Child 1999;80:343-347)
\end{abstract}

Keywords: acute viral bronchiolitis; bronchiolitis; wheezing; inhaled corticosteroids; budesonide

Acute viral bronchiolitis is the most common lower respiratory tract infection in infancy and up to $2.5 \%$ of all infants require hospital admission during winter epidemics. ${ }^{1}$ Although mortality is low and largely confined to those with congenital heart disease and other pulmonary diseases, subsequent respiratory problems are common. ${ }^{2-18}$ Follow up studies have suggested that in the two years after admission to hospital with acute viral bronchiolitis, the incidence of recurrent episodes of coughing and wheezing may be as high as $75 \% .{ }^{9}$ These problems become less common over the subsequent three years, ${ }^{19-22}$ but it has been estimated that they may account for $\sim 20 \%$ of all wheezing in preschool children. ${ }^{23}$

The results of randomised controlled trials assessing changes in symptomatology in infants with acute bronchiolitis suggest a variable response to both $\beta_{2}$ agonists and ipratropium bromide. A recent meta-analysis of these studies suggests a modest, short term improvement only. ${ }^{24}$ Theophylline has not been shown to be of benefit in acute bronchiolitis. ${ }^{25}$ The role of nebulised ribavirin also appears to be uncertain, with earlier studies suggesting a faster clinical improvement and shortening of the period of viral shedding. ${ }^{26-28}$ However, a metaanalysis of all suitable randomised controlled trials showed no significant improvement for clinically important outcomes. ${ }^{29}$ An initial, small, randomised controlled trial of systemic corticosteroids in acute bronchiolitis suggested significant short term benefit of this treatment. $^{30}$ All but one subsequent larger studies failed to demonstrate this same positive effect. ${ }^{30-38}$ None of these studies of intervention in the acute phase of the illness included information on long term outcomes. Therefore, there is currently no evidence that systemic steroids or any other treatment reduce the incidence of subsequent respiratory problems, common after acute viral bronchiolitis.

Three randomised controlled trials have examined the role of inhaled steroids for the prevention of recurrent wheezing after acute viral bronchiolitis. ${ }^{39-41}$ All of these studies concluded that nebulised steroids may be beneficial in this situation. However, problems with the efficacy and convenience of delivering inhaled steroids by means of a nebuliser have been noted. ${ }^{42}{ }^{43}$ An alternative system that has been shown to be an effective and convenient device for use in this age group is a metered dose inhaler with a modified spacer and face mask. $^{44}{ }^{45}$

The aim of our study was to assess the efficacy of inhaled budesonide by means of a metered dose inhaler with a modified spacer and face mask system in reducing the incidence of coughing and wheezing episodes during the first year after acute viral bronchiolitis.

\section{Methods}

The trial was a randomised, double blind, placebo controlled study and was approved by the ethics committee for each hospital. Written parental consent was obtained before inclusion.

Infants less than 12 completed months old with a clinical diagnosis of acute viral bronchiolitis requiring hospital admission were 
considered for enrolment into our study. The clinical diagnosis was based on the presence of tachypnoea (a respiratory rate $>40 / \mathrm{min}$ ), chest hyperinflation, soft tissue recession, and bilateral crackles, with or without wheezes. Patients with underlying cardiopulmonary disease, including congenital heart disease, bronchopulmonary dysplasia, and cystic fibrosis, along with those who had experienced respiratory problems in the neonatal period were excluded from our study. Any infant requiring mechanical ventilation during the present illness was also excluded.

On admission to hospital, a full history was recorded, including family history of atopy, parental smoking habits, and details of any previous respiratory symptoms. A nasopharyngeal aspirate was taken for respiratory syncytial virus immunoflourescence. Daily clinical assessment was made for each day of hospital admission. The remainder of the medical and nursing care provided during the stay in hospital was routine and any decisions regarding clinical care were made by medical and nursing staff not associated with our study.

When infants were considered to be ready for discharge from hospital they were randomised to receive either budesonide or placebo by means of a metered dose inhaler and modified spacer and face mask system, $200 \mu \mathrm{g}$ or one puff twice daily for the next eight weeks. This delivery system has been described previously for use in infants of similar age using the same medication. ${ }^{44}$ Parents of infants recruited to our study received instruction on the use of this device on the day of discharge from hospital and were asked to start treatment immediately after arrival home. They were also instructed to keep a diary card record of all respiratory symptoms, general practitioner and hospital visits, and medication prescribed and used over the next 12 months.

Outpatient clinic assessments were carried out 1, 2, 6, and 12 months after the initial hospital discharge date. At the first of these appointments, the parents' technique for administration of the budesonide or placebo via the delivery system was assessed as well as collection of diary card records and clinical examination. Subsequent appointments were for the purpose of diary card record collection and clinical examination only.

SAMPLE SIZE CALCULATION

A previous study in a similar population of infants with acute bronchiolitis found that $65 \%$ had episodes of cough and wheeze during the first year of follow up. ${ }^{22}$ To reduce this by $40-25 \%$ we calculated that 40 infants (20 in each study group) needed to be fully followed up for one year for the study to have $80 \%$ power at the $5 \%$ significance level. To ensure that full follow up data were collected from this number of patients, we planned to recruit 60 patients in total, allowing for follow up failures as a result of non-attendance and other possible violations of protocol.

\section{STATISTICAL ANALYSIS}

Demographic data and follow up data between the two study groups were compared using the Mann-Whitney U test for continuous variables. The $\chi^{2}$ test with Yates's correction was used for categorical variables, and Fisher's exact test was used when the expected frequency for any cell was less than five. To eliminate more trivial symptoms, only episodes of cough and wheeze that required either treatment by a general practitioner or in a hospital accident and emergency department were included in the statistical analysis.

\section{Results}

Sixty patients aged 1-42 weeks (median, 11 weeks) were initially randomised to receive either budesonide or placebo (30 to each group). Eight infants had been born prematurely, between 32 and 37 completed weeks' gestation. Although six of these infants were randomised to the placebo group and only two to the budesonide group, this difference was not significant (Fisher's exact $p$ value $=0.25$ )

Full follow up data were available for 49 of the 60 infants initially randomised. Of the other 11 patients, one was excluded after randomisation, but before receiving any trial medication, because he required mechanical ventilation during the acute phase of the initial bronchiolitic illness. Another patient was excluded at the time of the first follow up appointment for poor compliance. Four patients failed to attend any follow up appointment, one patient attended for two months, and four patients attended for six months only. All possible efforts were made to trace these cases. Of the 49 patients with full follow up, diary card entries were complete in 32 and partial in the other 17 cases.

Two adverse events were recorded during the treatment part of our study and neither of these were considered serious enough to consider breaking the randomisation code. One infant in the placebo group was admitted

Table 1 Demographic data and details of initial hospital admission

\begin{tabular}{llllll}
\hline & $\begin{array}{l}\text { Placebo } \\
(n=28)\end{array}$ & $\begin{array}{l}\text { Budesonide } \\
(n=26)\end{array}$ & \% difference (95\% CI) & $\chi^{2}$ & $p$ Value \\
\hline Median (range) age (weeks) & $10(1-38)$ & $11(3-42)$ & - & - & 0.70 \\
Boys (n) & 14 & 20 & $26.9(1.1$ to 52.7) & 3.12 & 0.08 \\
Family history of atopy (n) & 19 & 15 & $10.2(-15.6$ to 36.0) & 0.24 & 0.62 \\
Number with household smokers & 21 & 17 & $9.6(-14.8$ to 34.0) & 0.23 & 0.63 \\
Median (range) days in hospital & $4(1-14)$ & $3(1-13)$ & - & - & 0.75 \\
RSV positive on NPA (n) & $21^{\star}$ & $14 \dagger$ & $6.95(-12.5$ to 30.4) & 0.13 & 0.72 \\
Requiring oxygen (n) & 10 & 11 & $3.57(-19.4$ to 32.6) & 0.05 & 0.83 \\
Requiring NG feeds (n) & 15 & 13 & & & 0.07 \\
\hline
\end{tabular}

$\star_{\mathrm{n}}=23 ; \mathrm{t}_{\mathrm{n}}=17$.

RSV, respiratory syncitial virus; NPA, nasopharyngeal aspirate; NG, nasogastric. 
Table 2 Follow up data for months 1, 2, and 6 after acute bronchiolitis

\begin{tabular}{|c|c|c|c|c|c|c|}
\hline & \multicolumn{2}{|l|}{$\begin{array}{l}\text { Placebo } \\
(n=28)\end{array}$} & $\begin{array}{l}\text { Budesonide } \\
(n=26)\end{array}$ & $\%$ difference $(95 \%$ CI) & $\chi^{2}$ & $p$ Value \\
\hline \multicolumn{7}{|l|}{ Number with symptoms at } \\
\hline One month & 5 & \multicolumn{2}{|c|}{4} & $2.5(-17.4$ to 22.3$)$ & - & 1.00 \\
\hline Two months & 11 & \multicolumn{2}{|c|}{11} & $3.0(-23.2$ to 29.2$)$ & 0.05 & 0.82 \\
\hline Six months & $12^{\star}$ & \multicolumn{2}{|c|}{15} & $13.3(-13.4$ to 39.9$)$ & 0.48 & 0.49 \\
\hline \multicolumn{7}{|l|}{$\star_{\mathrm{n}}=27$} \\
\hline \multicolumn{7}{|c|}{ Table 3 Data for follow up 12 months after acute bronchiolitis } \\
\hline & & $\begin{array}{l}\text { Placebo } \\
(n=24)\end{array}$ & $\begin{array}{l}\text { Budesonide } \\
(n=25)\end{array}$ & $\%$ difference $(95 \%$ CI) & $\chi^{2}$ & $p$ Value \\
\hline Number with symptoms & & 12 & 21 & $34.0(9.37$ to 58.6$)$ & 4.98 & 0.03 \\
\hline Number with hospital admissions & & 6 & 5 & $5.0(-18.6$ to 28.4$)$ & 0.01 & 0.94 \\
\hline Number with $\geqslant 3$ symptom episodes & & \multirow{2}{*}{$\begin{array}{l}6 \\
1(0-11)\end{array}$} & 11 & $19.0(-7.7$ to 45.7$)$ & 1.20 & 0.27 \\
\hline Median (range) symptom episodes & & & $2(0-13)$ & - & - & 0.02 \\
\hline Median (range) symptom days & & $9(0-90)$ & $18(0-106)$ & - & - & 0.08 \\
\hline
\end{tabular}

to hospital with viral gastroenteritis and another infant, in the budesonide group, was readmitted to hospital with mild coughing and wheezing.

Demographic data were assessed for the 54 cases with any follow up data. Comparison between the two study groups for this is summarised in table 1 . There were no significant differences between those in the placebo group and those in the budesonide group for age, sex, family history of atopy (in first degree relatives), and prevalence of parents (or other household members) who smoked. The severity of the initial acute bronchiolitic illness was estimated by the length of stay in hospital along with the need for nasogastric feeding and supplementary oxygen. There were also no significant differences between the two study groups for any of these parameters.

The number of infants in each study group with symptoms of cough and wheeze that required treatment by the general practitioner or in a hospital accident and emergency department during the first 1,2 , and 6 months of follow up is shown in table 2. Medications prescribed included cough suppressants, oral and inhaled bronchodilators, and inhaled and systemic steroids. During this part of the follow up period, there were no significant differences between infants randomised to receive placebo after acute viral bronchiolitis and those who were given budesonide.

Table 3 shows follow up data for the full 12 month follow up period. Significantly more infants in the budesonide group had episodes of cough and wheeze that required treatment by the general practitioner or in a hospital accident and emergency department. The number of these symptom episodes was also greater in the budesonide group, but no significant difference was found for the number in each group with three or more episodes. The number of infants with episodes of cough and wheeze that were severe enough to merit hospital admission is also shown in table 3 . Again, no significant differences were found between the two study groups.

During randomisation there was no stratification for possible confounding variables such as the sex of the infant. Although there was no significant difference between the two groups for sex at the time of randomisation, a greater number of boys received budesonide and were then fully followed up and included in the final analysis. There were 24 of 30 boys, but only nine of 19 females with appreciable symptoms during the year of follow up. We therefore carried out a logistic regression analysis to assess whether receiving budesonide predicted having symptoms during the year of follow up, independent of being a boy. This analysis suggested that infants in the budesonide group did not have a significant increase in symptoms over the year of follow up $(\mathrm{p}=0.051)$.

\section{Discussion}

Our results suggest that budesonide given by means of a metered dose inhaler, spacer, and face mask system to infants with bronchiolitis immediately after hospital discharge is not effective for the prevention of subsequent episodes of coughing and wheezing. It is

Table 4 Previously published randomised controlled trials of inhaled steroids for the reduction of wheezing after bronchiolitis

\begin{tabular}{|c|c|c|c|c|c|}
\hline Reference & Inclusion criteria & Study groups & Sample size & Results & Comments \\
\hline Maayan et al $1986^{39}$ & $\begin{array}{l}\text { Recurrent wheeze after } \\
\text { bronchiolitis in infants aged } \\
3-9 \text { months (mean } 4 \\
\text { months) after bronchiolitis }\end{array}$ & $\begin{array}{l}\text { Nebulised } \\
\text { beclomethasone- }-100 \mu \mathrm{g} \text { tid } \\
\text { for two weeks or placebo }\end{array}$ & 9 (crossover) & $\begin{array}{l}\text { Decreased respiratory rate, } \\
\text { clinical score, and improved } \\
\text { pulmonary mechanics in } \\
\text { steroid treated group }\end{array}$ & $\begin{array}{l}\text { May have included patients } \\
\text { with atopic asthma rather } \\
\text { than acute bronchiolitis }\end{array}$ \\
\hline Carlsen et al $1988^{40}$ & $\begin{array}{l}\text { Age } 6 \text { months to } 2 \text { years. } \\
\text { Previous hospitalisation } \\
\text { with bronchiolitis and at } \\
\text { least one subsequent } \\
\text { episode of wheezing }\end{array}$ & $\begin{array}{l}\text { Nebulised } \\
\text { beclomethasone }-100 \mu \mathrm{g} \text { qid } \\
\text { for two weeks then } 100 \mu \mathrm{g} \text { bid } \\
\text { for six weeks or placebo }\end{array}$ & $\begin{array}{l}44 \text { (two } \\
\text { groups) }\end{array}$ & $\begin{array}{l}\text { Decreased number of } \\
\text { symptom episodes and } \\
\text { reduced requirement for } \\
\text { treatment in steroid treated } \\
\text { group }\end{array}$ & $\begin{array}{l}\text { May have included patients } \\
\text { with atopic asthma rather } \\
\text { than acute bronchiolitis }\end{array}$ \\
\hline Reijonen et al $1996^{41}$ & $\begin{array}{l}<2 \text { years old. Hospitalised } \\
\text { with bronchiolitis }\end{array}$ & $\begin{array}{l}\text { Nebulised budesonide- }-500 \\
\mu \mathrm{g} \text { bid for eight weeks then } \\
250 \mu \mathrm{g} \text { bid for eight weeks, or } \\
\text { sodium cromoglycate, or } \\
\text { placebo }\end{array}$ & $\begin{array}{l}100 \text { (three } \\
\text { groups) }\end{array}$ & $\begin{array}{l}\text { Decreased number of } \\
\text { symptom episodes and } \\
\text { reduced numbers of hospital } \\
\text { admissions in steroid treated } \\
\text { group }\end{array}$ & $\begin{array}{l}\text { No significant differences } \\
\text { between study groups if } \\
\text { atopic patients removed }\end{array}$ \\
\hline
\end{tabular}


possible that inhaled budesonide may have even worsened outcomes, but this becomes less likely once the effect of sex is taken into account. Other confounding variables could also have influenced the results or, alternatively, a type 1 error may have occurred. A true difference between the budesonide and placebo groups cannot be excluded, however, but this seems unlikely in view of the results of other studies of inhaled steroids during or after acute viral bronchiolitis.

Parent kept diary card data collection for infants and children with symptoms of coughing and wheezing has been criticised previously, because of poor correlation with less subjective methods of symptom assessment. ${ }^{46}$ Therefore, we attempted to improve objectivity in this study by only including symptom episodes that had been assessed and treated by a physician. This appears to have been justified by the fact that only $65 \%$ of patients with full follow up attendance had reliably completed diary cards.

Table 4 shows details of the three previous randomised controlled trials assessing the efficacy of inhaled steroids in this situation, which all had positive results. ${ }^{39-41}$ Inclusion criteria and the timing, method of delivery, and dose of inhaled steroids varied between all three studies and our own, and these differences might explain the conflicting results. Two of these studies based the initial diagnosis of acute viral bronchiolitis on the presence of acute tachypnoea, wheezing, cyanosis, and the use of accessory muscles. This is likely to lead to the inclusion of infants presenting with atopic asthma, rather than bronchiolitis. It has been suggested that if the diagnosis of acute viral bronchiolitis is limited to infants with fine crackles, with or without wheeze, the relation between atopy and bronchiolitis disappears. ${ }^{15} 1629$ When the atopic infants are removed from the analysis of the study by Reijonen et $a l,{ }^{41}$ the improvements on inhaled budesonide become non-significant, thus supporting this hypothesis. Further studies of the response to inhaled steroids in atopic infants admitted to hospital with bronchiolitis may help to clarify this.

Both Carlsen and colleagues ${ }^{40}$ and Reijonen and colleagues ${ }^{41}$ recruited patients up to 24 months of age, whereas our study only included infants up to 12 months old. It is possible that the response to inhaled steroids may be better in older children.

The timing of starting inhaled steroids also varied considerably between the studies. Maayan and colleagues ${ }^{39}$ and Carlsen and colleagues ${ }^{40}$ recruited patients who already had recurrent episodes of coughing and wheezing after bronchiolitis (that is, several months after acute bronchiolitis), whereas Reijonen and colleagues $^{41}$ initiated treatment on the second day of hospital admission and we did so immediately after hospital discharge.

Delivery of both bronchodilators and inhaled steroids to infants by means of the metered dose inhaler and modified spacer and face mask system has been shown previously to be safe, well tolerated, and effective. ${ }^{44}{ }^{45}$ There- fore, it seems unlikely that the negative findings of our study can be explained by inadequate delivery of medication. However, previous studies with positive results ${ }^{39-41}$ have all assessed the efficacy of nebulised steroids, and better delivery with this system cannot be ruled out.

In summary, our study suggests that the routine administration of budesonide by means of a metered dose inhaler, spacer, and face mask to all infants after hospitalisation with acute viral bronchiolitis cannot be recommended.

We are grateful to Dr J Alexander for his assistance with the statistical analysis. This study was funded by grants from the National Asthma Campaign and The St Thomas's Hospital Special Trustees.

1 Holberg CJ, Wright AL, Martinez FD, Ray CG, Taussig LM, Lebowitz MD. Risk factors for respiratory syncytial virus-associated lower respiratory illnesses in the first year of life. Am f Epidemiol 1991;133:1135-51.

2 Wittig HJ, Cranford NJ, Glaser J. The relationship between bronchiolitis and childhood asthma. A follow-up study of 100 cases of bronchiolitis in infancy. $\mathcal{F}$ Allergy 1959;30:1923.

3 Eisen AH, Bacal JL. The relationship of acute bronchiolitis to bronchial asthma: a 4-14 year follow up. Pediatrics 1963; 31:859-61.

4 Rooney JC, Williams HE. The relationship between proved iral bronchiolitis and subsequent wheezing. 7 Pediatr 1971;79:744.

5 Zweiman B, Schoenwetter WF, Pappano JE, Tempest B, Hildreth EA. Patterns of allergic respiratory disease in children with a past history of bronchiolitis. I Allergy Clin Immunol 1971;48:283-9.

6 Sims DG, Downham MAPS, Gardner PS, Webb JGK, Weightmann D. Study of 8 year old children with a history of respiratory syncytial virus bronchiolitis in infancy. BMF 1978;i:11-14.

7 Gurwitz D, Levison H. Increased incidence of bronchial reactivity in children with a history of bronchiolitis. $\mathcal{F}$ Pediatr 1981;98:551-5.

8 Mok JYQ, Simpson H. Outcome of acute lower respiratory infection in infants: preliminary report of seven-year infection in infants: preliminary rep

9 Henry RL, Hodges ICG, Milner AD, Stokes GM. Respiratory problems two years after acute bronchiolitis in infancy. Arch Dis Child 1983;58:713-16.

10 Mok JYQ, Simpson H. Symptoms, atopy and bronchial reactivity after lower respiratory infection in infancy. Arch Dis Child 1984;59:299-305.

11 Duiverman EJ, Neijens HJ, Van Strik R, Affourht MJ, Kerrebijn $\mathrm{KF}$. Lung function and bronchial responsiveness in children who had infantile bronchiolitis. Pediatr Pulmonol 1987;3:38-44.

12 Carlsen KH, Larsen S, Bjerve O, Leegaard J. Acute bronchiolitis: predisposing factors and characterisation of infants at risk. Pediatr Pulmonol 1987;3:153-60.

13 Carlsen KH, Larsen S, Orstavik I. Acute bronchiolitis in infancy. The relationship to later recurrent obstructive airways disease. Eur f Respir Dis 1987;70:86-92.

14 Rylander E, Eriksson M, Freyschuss U. Risk factors for occasional and recurrent wheezing after RSV infection in infancy. Acta Paediatr Scand 1988;77:711-15.

15 Sly PD, Hibbert ME. Childhood asthma following hospitalisation with acute viral bronchiolitis in infancy. Pediatr Pulmonol 1989;7:153-8.

16 Korppi M, Reijonen T, Poysa L, Juntunen-Backman K. A 2 to 3-year outcome after bronchiolitis. Am F Dis Child 1993; 147:628-31

17 Osundwa VM, Dawod ST, Ehlayel M. Recurrent wheezing in children with respiratory syncytial virus (RSV) bronchiolitis in Qatar. Eur f Pediatr 1993;152:1001-3.

18 Sigurs N, Bjamason R, Sigurbergsson F, Kjellman B, Bjorksten B. Asthma and immunoglobulin E antibodies after respiratory syncytial virus bronchiolitis: a prospective cohort study with matched controls. Pediatrics 1995;95: 500-5.

19 Pullan CR, Hey EN. Wheezing, asthma and pulmonary dysfunction 10 years after infection with respiratory syncytial virus in infancy. BMF 1982;284:1665-9.

20 Webb MSC, Henry RL, Milner AD, Stokes GM, Swarbrick AS. Continuing respiratory problems three and a half years after acute viral bronchiolitis. Arch Dis Child 1985;60: $1064-7$

21 McConnochie KM, Roghmann KJ. Wheezing at 8 and 13: changing importance of bronchiolitis and passive smoking. Pediatr Pulmonol 1989;6:138-46.

22 Murray M, Webb MSC, O'Callaghan C, Swarbrick AS, Milner AD. Respiratory status and allergy after bronchiolitis. Arch Dis Child 1992;67:482-7.

23 McConnochie KM, Roghmann KJ. Bronchiolitis as a possible cause of wheezing in childhood: new evidence. Pediatrics 1984;741:1-10. 
24 Kellner JD, Ohlsson A, Gadomski AM, Wang EEL. Efficacy of bronchodilator therapy in bronchiolitis - a metaanalysis.

25 Brooks L. Theophylline therapy in bronchiolitis. A retrospective study. Am f Dis Child 1981;135:934-6.

26 Hall CB, McBride JT, Walsh EE, et al. Aerosolized ribavirin treatment of infants with respiratory syncytial virus infection: a randomised double blind study. $N$ Engl f Med 1983;308:1443-7

27 Taber LH, Knight V, Gilbert BE, et al. Ribavirin treatment of bronchiolitis due to respiratory syncytial virus infection in infants. Pediatrics 1983;72:613-18.

28 Hall CB, McBride JT, Gala CL, Hildreth Sw, Schnabel KC. Ribavirin treatment of respiratory syncytial viral infection in infants with underlying cardiopulmonary disease. $7 A M A$ 1985;254:3047-51.

29 Randolph AG, Wang EEL. Ribavirin for respiratory syncytial virus lower respiratory tract infection: a systemsyncytial virus lower respiratory tract infection: a system-

30 Oski FA, Salitsky S, Barness LA. Steroid therapy in bronchiolitis: a double-blind study. Am f Dis Child bronchiolitis:

31 Sussman S, Grossman M, Magofinn R, Shielbe J. DexamPediatory tract infection in children. A controlled study. Pediatrics 1964;34:851.

32 Dabbous IA, Tkachyk JS, Stamm SJ. A double blind study on the effects of corticosteroids in the treatment of bronchiolitis. Pediatrics 1966;37:477-84

33 Connolly JH, Field CMB, Glasgow JTF, Slattery CM, MacLynn DM. A double blind trial of prednisolone in epidemic bronchiolitis due to respiratory syncytial virus. Acto Paediatr Scand 1969;58:116-20.

34 Leer JA, Green JL, Heimlich EM, et al. Corticosteroid treatment in bronchiolitis. Am f Dis Child 1969;117:495-503.

35 Springer C, Bar-Yishay E, Uwayyed K, Avital A, Vilozni D, Godfrey S. Corticosteroids do not affect the clinical or physiological status of infants with bronchiolitis. Pediatr Pulmonol 1990;9:181-5.
36 Roosevelt G, Sheehan K, Grupp-Phelan J, Tanz RR, Listernick R. Dexamethasone in bronchiolitis: a randomised controlled trial. Lancet 1996;348:292-5.

37 van Woensel JBM, Wolfs TFW, van Aalderen WMC, Brand PLP, Kimpen JLL. A randomised double-blind placebocontrolled trial of prednisolone in children hospitalised for respiratory syncytial virus bronchiolitis. Thorax 1997;52: 634-7.

38 De Boeck K, Van der Aa N, Van Lierde S, Corbeel L, Eeckels R. Respiratory syncytial virus bronchiolitis: a double blind dexamethasone efficacy study. F Pediatr 1997;131: 919-21.

39 Maayan C, Itzhaki T, Bar-Yishay E, Gross S, Tal A, Godfrey $S$. The functional response of infants with persistent wheezing to nebulised beclomethasone dipropionate. Pediatr Pulmonol 1986;2:9-14.

40 Carlsen KH, Leegaard J, Larsen S, Orstavik I. Nebulised beclomethasone dipropionate in recurrent obstructive episodes after bronchiolitis. Arch Dis Child 1988;63:1428-33.

41 Reijonen T, Korppi M, Kuikka L, Remes K. Antiinflammatory therapy reduces wheezing after bronchiolitis. Arch Pediatr Adolesc Med 1996;150:512-17.

42 Webb MSC, Milner AD, Hiller EJ, Henry RL. Nebulised beclomethasone dipropionate suspension. Arch Dis Child 1986;61:1108-10.

43 O'Callaghan C. Particle size of beclomethasone dipropionate produced by 2 nebulisers and 2 spacers. Thorax 1990;45:109-11.

44 O'Callaghan C, Milner AD, Swarbrick A. Spacer device with face mask attachment for giving bronchodilators to infants with asthma. BMF 1988;298:160-1.

45 Noble V, Ruggins NR, Everard ML, Milner AD. Inhaled budesonide for chronic wheezing under 18 months of age. Arch Dis Child 1992;67:285-8.

46 Archer LN, Simpson H. Night cough counts and diary card scores in asthma. Arch Dis Child 1985;60:473-4. 